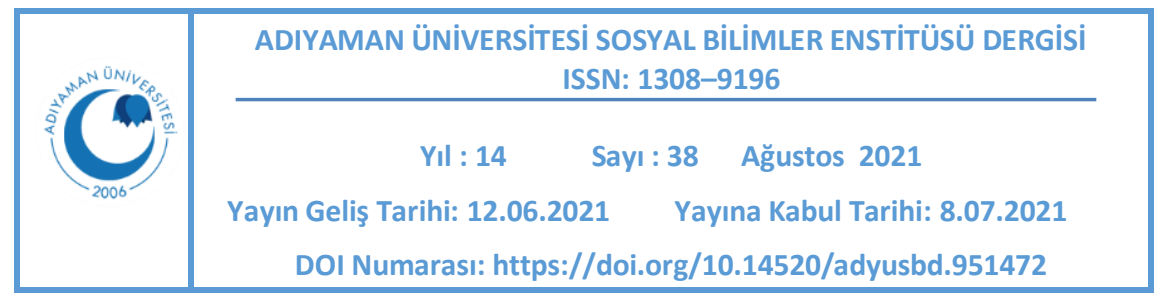

\title{
UNIVERSITIES IN EUROPE TAKEN AS A MODEL FOR THE \\ ESTABLISHMENT OF THE TURKISH HIGHER EDUCATION SYSTEM \\ OF THE REPUBLICAN ERA AND THEIR HISTORICAL \\ DEVELOPMENTS
}

\section{SEFA SALIH AYDEMIR*}

\begin{abstract}
From the Seljuk Empire and until the Turkish Republic, the Turkish higher education system was based on the madrasa tradition. In the late period of the Ottoman Empire, along with madrasa, which was the classic educational institution, besides military schools giving education in western style, opening civil educational institutions, similar to the university in Europe, started. The first schools opened were in the French model first, similar to the country and its cultural institutions, which the state sympathized with in the foreign policy, and the universities opened in the late periods until the end of the Second World War were tried to be built similar to the German Higher Education system. After the war, on the other hand, university institutions according to the Anglo-Saxon model started to be opened, too. While the institution of the university that developed in time through different models of different countries form with the historical processes and cultural texture of the country it is in, this institution was created by taking the models of the western state that is effective on Turkey as an example within the westernization activities rather than our sociological internal structure. In this study, the higher education systems in Europe that are taken as examples while creating our modern Turkish higher education system and their developments in history will be discussed.
\end{abstract}

Keywords: Europe, University, Republic of Turkey, Higher Education.

Dr. Öğr. Üyesi, Adıyaman Üniversitesi, Fen Edebiyat Fakültesi, Sosyoloji Bölümü, saydemir@adiyaman.edu.tr 


\title{
CUMHURIYET DÖNEMI TÜRK YÜKSEKÖĞRETIM SISTEMININ KURULMASINDA MODEL ALINAN AVRUPA'DAKI ÜNIVERSITELER VE TARIHSEL GELIŞiMLERi
}

\begin{abstract}
$\ddot{O} z$
Türk yükseköğretim sistemi Selçuklu Devleti'nden itibaren Türkiye Cumhuriyeti'ne gelene kadar medrese geleneğine dayanmaktaydı. Osmanlı Devleti'nin son döneminde klasik eğitim kurumu olan medreselerle beraber, batılı tarzda eğitim veren askeri okulların yanında, Avrupa'daki üniversiteye benzer sivil eğitim kurumları açma faaliyetleri başlar. Açılan ilk okullar, devletin dış politikada sempati duyduğu ülke ve onun kültürel müesseselerine benzer bir şekilde ilk önce Fransı modeli olup, son dönemlerden itibaren ikinci dünya Savaşının sonuna kadar geçen süre içinde açılan üniversiteler Alman Yükseköğretim sistemine benzer şekilde kurgulanmaya çalışııır. Savaş sonrası ise Anglo-Sakson modeline göre de üniversite kurumları açılmaya başlanır. Değişik ülkelerin farklı modelleri üzerinden zaman içerisinde gelişen üniversite kurumu, bulununlan ülkenin tarihsel süreçleri ve kültürel dokusu ile şekillenirken, Türkiye'de bu kurum kendi sosyolojik iç yapımızdan ziyade batılılaşma faaliyetleri içerisinde, Türkiye üzerinde etkin olan batılı devletin modelleri örnek alınarak oluşturulmuştu. Bu çalışmada modern Türk yükseköğretim sistemimizi oluştururken örnek alınan Avrupadaki yükseköğretim sistemleri ve onların tarih içerisindeki gelişimleri ele alınacaktır.
\end{abstract}

Anahtar Kelimeler: Avrupa, Üniversite, Türkiye Cumhuriyeti, Yükseköğretim.

\section{INTRODUCTION}

According to Meydan Larousse (1985), the concept of university, which comes from the Latin word Universitas, means the community of individuals that come together in line with independent and common interests and also to ensure safety against the church and regional power partners (Öztunalı, 2009; Erol, 2005; Goff, 2005). Taken in its broad meaning, universities form only one section of the activity area called higher education (Gürüz, 2003; Timur, 2000). From 
Universities in Europe Taken as A Model for The Establishment of The Turkish

Higher Education System of The Republican Era and Their Historical

Developments

Summerrians's invention of writing, many ancient civilizations have created an area of higher education in a way (Timur, 2000). However, when universities are approached in today's meaning, the description of a more or less autonomous institution consisting of teachers and students that came together to ensure the teaching of certain disciplines comes up (Charle \& Verger, 2005).

University institutions, which serve the development of a country in social and economic areas, bring up eminent cadres by giving education in high-level education, conduct studies in technological and scientific areas, and offer the results of the studies done for the benefit of the society. The development of a country is directly related to its production it carries through with knowledge and labor (Serin, 1979).

In today's world, the concept of the university is taken over by the concept of multiversity. The fact that the university moves away from containing the diffusiveness of social life within itself as a whole has caused the settlement of the concept of multiversity as a step taken towards the production of the knowledge that adapts to postmodern periods, providing the new needs of advanced capitalism, postmodern society, and academician groups (Charle \& Verger, 2005).

\subsection{The Formation of the Universities in Europe}

The concept of the university first came up in the society in Western Europe after the XIth century and the first university institutions rose in the XIIth century (Gümüş, 2010; Erol, 2005) in Italy, France, and England (Goff, 2005; Erol, 2005). This institution, which is also one of the most important elements of cultural domination (Timur, 2000), expanded through all Europe first and then to other 
continents especially in the XIXth and XXth centuries after going through various phases.

\subsection{University in First and Middle Ages}

The first signs of higher education came up with Academia's that contain literary and scientific researches within itself ever since the first ages (Mansel, 1984; Hakan, 1982). The first examples go back to Plato's Academia (400, b.c.), Lyceum (387, b.c.) of Plato's student Aristotle, higher education institutions of the Roman period, and even the Museum of Alexandria which was in the status of a research center and which contained a significant library within itself (Erdem, 2006; Gürüz, 2003; Mansel, 1984; Timur, 2000).

Among these institutions, Mouseidon, which had the status of a museum in Alexandria, had an important place (Atılgan, 2005; Timur, 2000). This institution, consisting of a dean and members who devoted their lives to scientific research and received a salary from the state, also had the characteristic of a kind of religious community worshiping Mousas (Thiasos) (Mansel, 1984). However, neither Musaion nor Akademia was a university in the modern-day sense (Timur, 2000), but an institute that only engaged in scientific research (Ülken, 1970; Mansel, 1984; Timur, 2000). In time, the library, which was constituted to help the scientists working here in their studies and which initially contained a few hundred thousand papyrus scrolls, became the richest library of its time (Alar, 2001; Ortaylı, 2006; Mansel, 1984). Apart from this, a zoo that contained some rare foreign animals, an observatory, and an anatomy institution was constituted in Alexandria (Mansel, 1984).

In the IInd century B.C, when Evergetes the king of Egypt displaced the scientists out of Alexandria and later after the Alexandria library was burned down during the invasion of the Roman Empire in 48 B.C., Alexandria started to lose its charm 
Universities in Europe Taken as A Model for The Establishment of The Turkish

Higher Education System of The Republican Era and Their Historical

Developments

and the scientists there migrated to Bergama, which is the capital city of Attalos.

With the invention of parchment, although books were sent to several places in some periods, they ensured this city become a big science center and gain a rich library beside the king's court (Alar, 2001; Mansel, 1984). Upon the passing of Bergama to the Romans, the center of scientific research shifted first to Rhodes and then to Rome and remained in this city for a long time (Üreten, 2006; Mansel, 1984). The first examples of today's faculties were the continuation of Roman law schools, which were considered as a kind of higher education institution (Goff, 2005), and they emerged with the evolution of Stadium Generale schools which were directly subordinate to the diocese1 (Meydan Larousse, 1985).

Universities of Bologna (1080), 2 Paris (1160), and Oxford (1167) which came up at the beginning of the XIIth century in the Middle Age and completed their formation around the same time were the first universities to be established (Janin, 2008; Pedersen, 1997; Aytaç, 2009, Gürüz, 2003). These universities, which were quite developed for their time in terms of their institutional, social, and intellectual structures, are considered as the heir of a long historical background today (Charle \& Verger, 2005).3

\footnotetext{
${ }^{1}$ The cathedral, the monastery schools, or the centers in the church where lessons were given in a particular area before the emergence of universities in the Middle Ages was called Studium Generale. Universities opened in the Middle Ages continued to be called Studium Generale for a long time, and this word was replaced by the word "Universitas" by evolving over time (Rukancı \& Anameriç, 2004; Gürüz, 2003).

2 The University of Bologna, which accepts its year of establishment as 1088 , celebrated its 900th anniversary in 1988 with a big ceremony (Rüegg, 1992; Gürüz, 2003).

${ }^{3}$ The Universities of Montpellier, Padua, Orleans, and Cambridge, which were established at the same time as Bologna, Paris, and Oxford, institutionalization processes of which were exactly between 1200-1215, are the seven oldest universities that are still active. (Gürüz, 2003)
}

Adıyaman Üniversitesi Sosyal Bilimler Enstitüsü Dergisi, Yıl: 14, Sayı: 38, Ağustos 2021 
One of the common characteristics of universities in this period was their organization.4 Teachers and/or students that came together to establish a formal university used to elect representatives by giving themselves statuses of various levels, and organize in order to both help each other, protect themselves against the public or local authorities, and bring an autonomous structure to the education activity (Charle \& Verger, 2005; Erol, 2005; Goff, 2005).

Another common feature of these universities is that they consciously emerged from the influence of the regional diocese. These universities were under the auspices of the Papacy and the King, who wanted to provide a counterweight to the local churches and they declared that they had the capacity of being able to accept students from the whole Christian sphere, and rose to the status of an international authority in time (Charle \& Verger, 2005; Ülken, 1970; Goff, 2005).

Around 1300 there were only twelve or thirteen universities in Europe giving education (Charle \& Verger, 2005). During this period, the emergence of the first universities in the Germanic world and Central Europe is an important, remarkable phenomenon. Some of these universities that were established in Prag in 1347, Krakow in 1364, Vienna in 1365, Pecs in 1367, Heidelberg in 1386, St. Andrews in 1413, Louvain in 1425, Basel in 1459, Uppsala and Copenhagen in 1478 had difficulty in leaping forward due to being underdeveloped compared to Western Europe countries (Goff, 2005; Charle \& Verger, 2005; Gürüz, 2003). The increase in the number of universities came to 28 in the year 1378, t0 31, in 1400, and by the year 1500, the number of universities in Europe increased up to 63

\footnotetext{
${ }^{4}$ Bologna and Paris Universities are different from each other in terms of organization models; other universities were organized according to these models. In the Bologna model, the university was a guild system where the lecturers were excluded and the unison of students was formed. In the models Paris and, following that, Oxford, it was the guild organization formed by the professors coming together. (Ülgen, 2010; Erol, 2005; Rukancı \& Anameriç, 2004; Timur, 2000).
} 
Universities in Europe Taken as A Model for The Establishment of The Turkish

Higher Education System of The Republican Era and Their Historical

Developments

(Öztunalı, 2009; Gürüz, 2003). The great religious division (1378-1417), which divided Europe into two opposing domains, precipitated the rise of states and national churches. The universities in France, Spain, and Germany benefited the most from these developments (Charle \& Verger, 2005).

Another feature of this period is that the political powers were interested in the university. They dominated over universities with various pressures such as political control, restriction of freedoms and privileges, and interference in teacher appointments and student registrations. Old universities like Paris resist losing their old autonomies. However, financial difficulties, the incompetence of the university administration, the appeal of government service, and political activity suppress this resistance (Timur, 2000; Charle \& Verger, 2005).

One of the main plus values brought by the universities of this period is that the first steps to give importance to scientific development and research, albeit obligatory, are taken. Apart from that, another positive situation was that with the diversification of disciplines (poetry, ethics, chemistry, geography, history, natural history, meteorology, botany, economics, physics) in universities, reconciliation was brought to the agenda, too (Burke, 2001).

Besides religious and political concerns, even more important than those, the increasing financial requirements of universities were the factors that made these institutions dependent on local powers (Gürüz, 2003). Especially in the last periods of the Middle Age, financial subjects gained great significance in terms of the development of the universities. Universities providing their financial income from internal (registration and graduation fee, exemptions, collecting money from the students, disciplinary penalties) and external (religious donations, salaries coming from the king, duke, or local authorities, gifts and legacies, donations, etc.) sources ran out of these sources quickly with the development of universities and the increase of investments (buildings, libraries, houses, etc.), and spendings such as teacher salaries, administration costs, officer salaries, 
cases, religious and academic ceremonies, and the maintenance of the buildings(Geuna, 1996;Timur, 2000).

The increasing financial requirements of universities, combined with the political and religious changes that emerged in the late Middle Ages, made universities dependent on foreign powers and unsettled their supranational structure (Timur, 2000; Ülken, 1970). This dependence on local powers led universities to assume a more local character. Student organizations had started to lose their importance and autonomy; along with local authorities, the rector, senate, dean, faculty board started to represent the power within the university (Geuna, 1996; Gürüz, 2003; Timur, 2000).5

The first signs of these changes were seen in curriculum conservatism. This conservatism had led to the development of alternative institutions to the university at the end of the XVth century and in the XXIst century. 6 Institutions like these played a central role in the development of knowledge. Apart from this, non-university institutions, providing vocational training in engineering or state administration, emerged (Charle \& Verger, 2005). Although there was an increase in the number of universities due to the sectarian war in Europe towards the end of the XVIIIth century, the development of vocational training outside the university led to great decreases in the number of students. Except for the

\footnotetext{
${ }^{5}$ The social and legal privileges students and teachers gained at universities throughout the Middle Ages can be summarized as follows: 1) There is a right to be judged only before the school administrator, the oldest lecturer, or the bishop in any civil action against students. 2) They provide convenience for the provision of places where especially students from abroad can stay. 3) Full subsistence of students is provided by local powers such as municipality and church. 4) The safety of property and life of students, lecturers, and their relatives are ensured. 5) Rental and lending processes are organized for the convenient supply of textbooks. 6) Financial resources are provided for the research. 7) They have the right to strike because of adversity experienced. 8) Universities have the right to organize their own curriculum and various criteria. (Rukancı \& Anameriç, 2004). 6 In the year 1606, Galileo started working in the non-university research institution named Accademia dei Lincei, the first Academy of Sciences in today's meaning, arguing that it was not possible to work comfortably in universities for a variety of reasons. (Gürüz, 2003)
} 

Higher Education System of The Republican Era and Their Historical Developments

Netherlands, Scotland, and some German universities, all universities became self-directed institutions and all universities in France were closed with the 7 Le Chapelier Law. From the end of the XVIIIth century, a complete crisis situation arose in universities. 8

\subsection{The Industrial Revolution and Universities in Modern Age}

Although universities showed regional and intentional diffirences, modern universities of today started to shape in the XIXth century.9 Universities, slowly getting out of the domination of the clergy since the XVIIth century, became

\footnotetext{
7 Le Chapelier Law (1791): After the French Revolution in 1789, universities, which were considered as an aristocratic extension of the old regime under the influence of the church, were closed, along with various professional guilds.Instead of re-opening the universities that were closed in 1806, Napoleon Bonaparte (1769-1821), who proclaimed his emperorship in 1804, established a system of Academies, which values vocational education, by bringing a model of hierarchic structuring instead of autonomy. (Gürüz, 2003; Timur, 2000).

8 The general characteristics of pre-crisis European universities between the centuries XV and XVII are as follows: 1) As the influence of the church diminished over time, the humanist and rational approach began to gain importance instead of scholastic thought. 2) As a result of the increasing influence of the king and local authorities on universities, the course curriculum began to change in line with these pressures. 3) The lectern system began to settle, student unions started to lose their power and efficiency over time, and the authority passed to the rector and in-university institutions. 4) Non-university academies started to gain increasing importance in scientific activities, scientific studies gained importance in job assignments such as teaching. 5) Non-university higher education institutions that focus on vocational education started developing, the importance of vocational competence certificates instead of diplomas increased. 6) Universities began to rapidly expand outside of continental Europe as well due to various reasons such as sectarian wars. (Öztunalı, 2009).

9 The basic elements of the new understanding in universities of the XIXth century are stated under the following headings: 1) Academic research is the most fundamental activity of the university. 2) Values are carried by prioritizing thought and attitude formation; knowledge and skills are tried to be developed by modernizing elements of classical thought. 3) Information obtained from the research findings is passed to the university students. 4) Knowledge and findings obtained at the university are aimed to be provided to the community service (Oosterlinck, 2002).
} 
institutions where the children of noble and wealthy families benefited from in time (Özturanlı, 2009; Gürüz, 2003; Timur, 2000).

In addition to the strengthening of the nation-states and local principalities in the XIXth century, universities took an extremely important step by opening up to all segments of society due to the competitive environment brought by the sectarian war (Charle \& Verger, 2005).10

After this date, everyone that had talent was eligible to benefit from the university. In England, in the second quarter of the XIXth century, under the leadership of J. Bentham, one of the pioneers of pragmatism, University College London opened its doors to all segments of society (Reed, 2004; Rüegg, 2004; Semmel, 1961; Feingold, 2006; Charle \& Verger, 2005). These steps have been of great importance in shaping the modern university model. Since universities like Oxford and Cambridge were late to these implementations their scientific and intellectual levels fell behind (Charle \& Verger, 2005).

German universities are among the ones that were affected the most by the events of the revolution. It is usually stated that the university reform actualized by Wilhelm von Humboldt in Germany and the German idealism played a great role in the formation of the modern university. This model set an example for some countries like America (Ana Britanica, 2005). The German university model has the characteristic of revolution even only by including the research activities to the university structure as the main mission (Meray, 1971; Antalyalı, 2008).

\footnotetext{
${ }^{10}$ As a result of the rivalry between Protestants and Catholics, although a total of 137 universities were established between 1500 and 1800 A.D., nearly 50 of them either closed down or had to merge with another university over time. (Öztunalı, 2009).
}

Adıyaman Üniversitesi Sosyal Bilimler Enstitüsü Dergisi, Yıl: 14, Sayı:38, Ağustos 2021 
Universities in Europe Taken as A Model for The Establishment of The Turkish

Higher Education System of The Republican Era and Their Historical

Developments

Based on the philosophical principles of German idealism, Humboldt's university model integrates the following different elements (Özturanlı, 2009; Gürüz, 2003):

- Science and education: The knowledge produced by the university is a value in itself, without being divided into sections and without a designed purpose.

- Freedom in education and research, the oneness of science, commitment to the necessity of research: According to Humboldt, the obligation of the university is not only to protect the knowledge and pass it to the students but also to produce knowledge without any purpose. The owner of the university is the nation; the state is only responsible for providing the necessary conditions for scientific studies.

In general terms, the first half of the XIXth century contains examples of breaking away from the old university heritage. As a result of the missionary and colonialism activities, European universities expanded to the whole world (From the Pacific to Urals, India, and the continent of America) (Timur, 2000; Gürüz, 2003). Although the classic German model was effective to a large extent, the French-style 11centralized statist models and English-style12 college model maintains their importance, too. With the spread of research or vocational education, university education also gained new functions. Around the middle of the XXth century, higher education became an important institution for societies

\footnotetext{
${ }^{11}$ Compared to other European education systems, the French education system in the first half of the XIXth century was extremely unique since it was reconstructed, starting from zero. Whereas in other countries, medieval or old regime features remained, despite partial reforms. (Charle \& Verger, 2005).

12 In this period and until the Second World War, one of the main originalities of English higher education was that it gradually established institutions in the colonies and dominions that made up the world's largest empire at the level of those of the metropolis. For example, while there were no Western-style universities in India in 1800, 17 universities were established in 1939. Besides, colleges established in America form the basis of today's famous universities as well. (Charle \& Verger, 2005; Timur, 2000)
}

Adıyaman Üniversitesi Sosyal Bilimler Enstitüsü Dergisi, Yıl: 14, Sayı: 38, Ağustos 2021 
in contact with Europe. In this period, universities were in the status of being the field of social, scientific, and even political innovations since they play a significant role in the formation of future cadres. This situation was received with suspicion by all authoritarian or dictatorship regimes wanting to shape international activities and social hierarchies unambivalently. On the other hand, looking at the subject in global terms, it is seen that most of the significant transitions of XXth century societies

were shaped in this atmosphere (Charle \& Verger, 2005). After the Second World War, even the most traditional societies had to restructure their university structures completely (Antalyalı, 2007).

Table1Percentage of Schooling Rates in Higher Education in Some Western Countries; (ages 20-24) (Charle \& Verger, 2005);

\begin{tabular}{|c|c|c|c|c|c|c|c|c|c|c|}
\hline Countries & 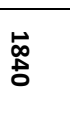 & 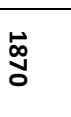 & $\begin{array}{l}\llcorner \\
\infty \\
\infty \\
0\end{array}$ & $\begin{array}{l}\stackrel{\circ}{\circ} \\
\stackrel{\Xi}{0}\end{array}$ & ๖े & $\begin{array}{l}\stackrel{\bullet}{\circ} \\
\stackrel{\Delta}{\circ}\end{array}$ & $\begin{array}{l}\stackrel{\bullet}{0} \\
\text { N }\end{array}$ & 卢 & $\underset{ٍ}{\bullet}$ & 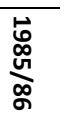 \\
\hline England & & 0.4 & 0.6 & 0.7 & 0.8 & 1.3 & 1.6 & 1.9 & 16.7 & 22.3 \\
\hline Germany & & 0.6 & 0.6 & 0.6 & 1.0 & 1.2 & 1.9 & 2.6 & 14.7 & 29.4 \\
\hline Austria & 0.9 & 0.7 & 1.0 & 0.9 & 1.1 & 3.8 & & & & 28 \\
\hline Belgium & 0.5 & 0.7 & 1.0 & 1.0 & 0.9 & 1.3 & & & 17.6 & 32.2 \\
\hline Scotland & & 1.4 & 1.9 & 1.8 & 1.4 & 1.9 & & & & \\
\hline Spain & & 0.9 & 1.0 & & & 1.2 & & & 9.8 & 30.2 \\
\hline Finland & 0.3 & 0.4 & 0.4 & 1.1 & 1.2 & 1.2 & & & & 35 \\
\hline France & & 0.5 & 0.6 & 0.9 & 1.2 & 1.7 & 2.0 & 2.9 & 19.4 & 30 \\
\hline Italy & & 0.5 & 0.5 & 0.8 & 1.0 & 1.1 & & & 19.1 & 26.1 \\
\hline Norway & & 0.7 & 0.5 & 1.0 & 0.7 & 0.8 & & & & 28 \\
\hline The & 0.6 & 0.4 & 0.5 & 0.7 & 0.7 & 1.1 & & & 20.9 & 31.4 \\
\hline Portugal & & 0.2 & 0.2 & 0.3 & 0.3 & 0.2 & & & 10 & 11.3 \\
\hline
\end{tabular}


Universities in Europe Taken as A Model for The Establishment of The Turkish

Higher Education System of The Republican Era and Their Historical

Developments

\begin{tabular}{lccccccccc}
\hline Russia & 0.1 & 0.1 & & 0.2 & 0.8 & & 4.3 & 31 & \\
Sweden & 0.5 & $\overline{0.6}$ & 0.9 & 0.7 & 0.9 & & & & 36.9 \\
Switzerland & & 0.7 & 0.9 & 1.4 & 2.2 & & & & 23 \\
USA & 2.3 & 3.4 & 3.5 & 5.0 & 5.6 & 9.0 & 11. & 49.3 & 64.4 \\
\hline
\end{tabular}

Another problem that universities across world have had to solve has been the difficult process of linking higher education and research. The differentiation between these two activities started before the Second World War. During and after the First and Second World Wars the purpose of scientific research and the functions of the universities started to differ greatly. In this period, scientists started to prioritize research that would contribute to the military power of the country in their studies. New vehicles for military air transport and communication, space studies, the production and development of nuclear or chemical weapons of mass destruction began to come to the fore more (As cited in: Antalyalı, 2007; Timur, 2000; Gürüz, 2003).13 In addition, after the Second World War, universities began to service the state and market economy more. In this period, which was called the cold war period, the effort to serve the nationstate was seen as the main duty of universities (As cited in Antalyalı, 2007).

\footnotetext{
${ }^{13}$ During the Cold War, military research activities became the most important priority of the American government; while appropriation allocated to universities from the budget for this purpose was around 1 billion dollars in 1950, this figure increased up to 21 billion dollars in 1996 (Gürüz, 2003).
}

Adıyaman Üniversitesi Sosyal Bilimler Enstitüsü Dergisi, Yıl: 14, Sayı: 38, Ağustos 2021 
Table2 From the Church-Oriented University to the Mass-Educational University, Stages the University Has Gone Through Structurally (Tekeli, 2003);

\begin{tabular}{|c|c|c|c|}
\hline & $\begin{array}{l}\text { Church-Based } \\
\text { University }\end{array}$ & $\begin{array}{l}\text { Nation-State } \\
\text { University } \\
\text { (Humboldt } \\
\text { University) }\end{array}$ & $\begin{array}{c}\text { Information } \\
\text { Society University } \\
\text { (Multiversite) }\end{array}$ \\
\hline Function & Teaching only & $\begin{array}{l}\text { Teaching, } \\
\text { research, and } \\
\text { cultural } \\
\text { transformation }\end{array}$ & $\begin{array}{l}\text { Division in } \\
\text { teaching, } \\
\text { research, service } \\
\text { to society }\end{array}$ \\
\hline Students & A small number & Elite education & Mass education \\
\hline Organization & $\begin{array}{l}\text { Student or faculty } \\
\text { members guild }\end{array}$ & $\begin{array}{l}\text { Academician } \\
\text { community }\end{array}$ & $\begin{array}{l}\text { A complex of } \\
\text { organizations } \\
\text { where the } \\
\text { distinction } \\
\text { between the } \\
\text { inside and outside } \\
\text { of the university } \\
\text { fades }\end{array}$ \\
\hline Administration & $\begin{array}{c}\text { Collegial } \\
\text { administration } \\
\text { model }\end{array}$ & $\begin{array}{l}\text { Collegial } \\
\text { administration } \\
\text { model. The rector } \\
\text { is elected for a } \\
\text { short time. }\end{array}$ & $\begin{array}{l}\text { Entrepreneurial } \\
\text { management } \\
\text { under the } \\
\text { leadership of the } \\
\text { rector, partly } \\
\text { collegial, partly in } \\
\text { a total quality } \\
\text { manner }\end{array}$ \\
\hline Financing & $\begin{array}{c}\text { Students to a large } \\
\text { extent }\end{array}$ & State & $\begin{array}{l}\text { Student-state- } \\
\text { market }\end{array}$ \\
\hline Language & Latin & National Language & English \\
\hline Diploma validity & $\begin{array}{l}\text { In the whole } \\
\text { Christian world }\end{array}$ & $\begin{array}{l}\text { Within the nation- } \\
\text { state }\end{array}$ & $\begin{array}{l}\text { International, life- } \\
\text { long learning } \\
\text { regardless of } \\
\text { diploma }\end{array}$ \\
\hline Specialization & $\begin{array}{l}\text { No areas of } \\
\text { specialization }\end{array}$ & $\begin{array}{l}\text { Specialized lectern } \\
\text { or institute }\end{array}$ & $\begin{array}{c}\text { Research } \\
\text { professor group }\end{array}$ \\
\hline
\end{tabular}


Universities in Europe Taken as A Model for The Establishment of The Turkish

Higher Education System of The Republican Era and Their Historical

Developments

\begin{tabular}{l|c|c|c}
\hline Curriculum & $\begin{array}{c}\text { A curriculum that is } \\
\text { compromised on, } \\
\text { and valid } \\
\text { everywhere }\end{array}$ & $\begin{array}{c}\text { Not oriented } \\
\text { towards a } \\
\text { different } \\
\text { profession in each } \\
\text { university }\end{array}$ & $\begin{array}{c}\text { Modular programs } \\
\text { for consumer } \\
\text { trends }\end{array}$ \\
\hline Audit & $\begin{array}{c}\text { The papacy has the } \\
\text { right to audit. }\end{array}$ & $\begin{array}{c}\text { Only the expenses } \\
\text { are audited. }\end{array}$ & $\begin{array}{c}\text { External } \\
\text { accreditation, } \\
\text { versatile } \\
\text { evaluation of the } \\
\text { lecturers }\end{array}$ \\
\hline
\end{tabular}

\section{CONCLUSION}

While only education was carried out in the church-oriented university, in nationuniversity, research and community service functions of teaching came to the fore as well. Multiversity, on the other hand, has become an institution in which education has become massive and gained an international quality, and with the help of capitalism, it has become an institution oriented towards consumer trends.

Public and private actors, especially researchers, have tended to autonomize research institutions as science and tech, military and economic practices have become an important purpose of contemporary societies. Despite the big changes they have gone through since the XIIIth century, universities are regarded as the exit way of the international adventure which is constantly threatened by social forces (Charle \& Verger, 2005). 


\section{REFERENCES}

Alar, A. (2001). Kütüphaneciliğin tarihçesi ve ilk kütüphaneler. Atatürk Üniversitesi Türkiyat Araştırmaları Enstitüsü Dergisi. 0(16): 295-308.

Ana Britannica. (2005). Cilt XXI, Ana Yayıncılık Aş.

Antalyalı, Ö. L. (2007). Tarihsel süreç içerisinde üniversite misyonlarının oluşumu. Süleyman Demirel Üniversitesi Sosyal Bilimler Enstitüsü Dergisi. 0(6): 2540.

Antalyalı, Ö. L. (2008). Türkiye üniversitelerinin örgütsel etkinlik alanları: öğretim üyeleri üzerinde bir araştırma. [Yayımlanmamış Doktora Tezi]. Süleyman Demirel Üniversitesi Sosyal Bilimler Enstitüsü.

Atılgan, M. (2005). Başlangıçtan 19. yüzyıla tıp kütüphaneleri. Oluşum Türk Kütüphaneciler Derneği Edirne Şubesi Yayın Organı. 0(51): 91-119.

Aytaç, K. (2009). Avrupa eğitim tarihi. Doğu Batı Yayınları.

Burke, P. (2001). Bilginin toplumsal tarihi. M.Tunçay (Çev.). Tarih Vakfı Yurt Yayınları.

Charle, C. \& Verger, J. (2005). Üniversitelerin Tarihi. Ankara: Dost Kitabevi Yayınları.

Erdem, A. R. (2006). Dünyadaki yükseköğretimin değişimi. Selçuk Üniversitesi Sosyal Bilimler Enstitüsü Dergisi. 0(15): 299-314.

Erol, B. (2005). “Orta çağ Avrupası ve Üniversiteler”. Doğu Batı Dergisi. 8(33): 8197.

Feingold, M. (2006). History of university. (Volume XXI/1). Oxford University Pres.

Geuna, A. (1996). European universities: an Interpretive history. University of Limburg.

Goff, J. L. (2005). “Orta çağda Batı Avrupa”. Doğu Batı Dergisi. 8(33): 39-68.

Gümüş, T. T. (2010). ortaçağ'dan erken modern döneme batı Avrupa'da eğitim tarihi: yeni yaklaşımlar. Mersin Üniversitesi Eğitim Fakültesi Dergisi. 6(1): 25-40.

Gürüz, K. (2003). Dünyada ve Türkiye'de Yükseköğretim, Tarihçe ve Bugünkü Sevk ve Idare Sistemleri. Ankara: Öğrenci Seçme ve Yerleştirme Merkezi Yayınları. 
Universities in Europe Taken as A Model for The Establishment of The Turkish

Higher Education System of The Republican Era and Their Historical

Developments

Hakan, A. (1982). Dünyada ve Türkiyede akademilerin tarihçesi ve bugünkü durumu. Ankara Üniversitesi Eğitim Bilimleri Fakültesi Dergisi. 15(2): 221238.

Janin, H. (2008). The university in medieval life. Mc Farland Company Inc.

Mansel, A. M. (1984). Ege ve Yunan Tarihi. Ankara: Türk Tarih Kurumu (TTK) Basımevi.

Meydan Larousse, (1985). (Cilt 12). Meydan Yayınevi.

Ortaylı, İ. (2006). İskenderiye kütüphanesi. Türk Kütüphaneciliği. 20(1): 85-88

Oosterlinck, A. (2002). Knowledge management in post-secondary education: universities. OECD Working Paper. https://www.oecd.org/innovation/research/2074921.pdf (11.04.2020).

Pedersen, O. (1997). The first universities. Cambridge University Pres.

Reed, D. (2004). Universities and the promotion of corporate responsibility: reinterpreting the liberal arts tradition. Journal of Academic Ethics. 2(1): 3-41.

Rukancı, F. \& Anameriç, H. (2004). Orta çağda ilk üniversiteler: studium generale. Felsefe Dünyası. 39(1): 170-186.

Rüegg, W. (Ed.). (1992). A history of the university in Europe. (Volue I). Cambridge University Pres.

Rüegg, W. (Ed.). (2004). A history of the university in Europe. (Volue III). Cambridge University Pres.

Semmel, S. (1961). The philosophic radicals and colonialism. The Journey of Economic History. 21(4): 513-525.

Serin, N. (1979). Eğitim Ekonomisi. Ankara: Ankara Üniversitesi Yayınları.

Tekeli, İ. (2003). Eğitim üzerine düşünmek. TÜBA.

Timur, T. (2000). Toplumsal Değişme ve Üniversiteler. Ankara: Imge Kitabevi.

Ülken, H. Z. (1970). "Batı Üniversitelerinin Gelişimi, Laiklik ve Fikir Hürlüğü İçin Savaşı". Ankara Üniversitesi Eğitim Bilimleri Dergisi. 3(1): 1-34.

Üreten, H. (2008). Antikçağ Anadolu'sunda bir kültür merkezi pergamon- kraliyetkütüphanesi. Türk Kütüphaneciliği. 22(4): 435-450. 
Öztunalı, Ö. (2009). Üniversiteler Tarihi ve Vakıf Üniversiteleri. (2. Baskı). İstanbul: İstanbul Kültür Üniversitesi Yayınları.

\section{GENiŞLETILMiş ÖZET}

\section{Giriş}

Eğitim öğretim kurumları arasında en yüksek düzeyde eğitim veren ve bilimsel araştırmaların yapıldığı üniversiteler, gelişmişlik seviyesini yükseltmek isteyen bir ülke için hayati öneme sahiptir. Dünya üzerindeki ülkelerin yerel kültürel yapıları nedeniyle farklı gelişim özellikleri kazanan ve birbirinden ayrı şekilde kurumsallaşan yükseköğretim müesseseleri, son yıllarda vizyon ve misyon açısından biraz daha evrensel benzer özellikler taşımaya başlar. Asırlar boyu farklı veya benzer ad, misyon veya örgütleniş biçimleriyle varoluş mücadelesi veren yükseköğretim kurumlarının önemi zaman içerisinde tarihteki çeşitli Türk-İslam devletlerince de benimsenmişti. Ülkenin nitelikli eleman ihtiyacını karşılamak için birçok farklı yerde ve sayıda medreseler açılır. Ancak yıllar içerisinde öncü vizyoner niteliğini kaybetmeye başlayan medrese kurumları devletlerin ihtiyaçlarına cevap verememeye başladılar. Özellikle Osmanlı Devleti'nin son dönemleri ve Türkiye Cumhuriyeti'nin ilk dönemlerinden itibaren Avrupa'da yükseköğretim alanında faaliyet gösteren üniversite kurumları model alınmaya başlanır. Ancak, Avrupa'daki üniversite kurumu da tek tipte olmayıp, bulundukları ülkelerin kültürel özellikleri itibarıyla çok farklı yapılanmada ve değişik anlayış ile çok uzun zaman dilimleri içinde gelişmişlerdir.

\section{Metot}

$\mathrm{Bu}$ araştırmanın amacı, Selçuklu Devleti döneminden itibaren Türk-İslam devletlerinin yükseköğretim kurumu olan medreselerin zaman içerisinde işlevini kaybetmesi üzerine Osmanlı Devleti'nin son dönemlerinden itibaren kurulmaya başlayan ve Türkiye Cumhuriyeti döneminin ilk yıllarından itibaren yaygınlaşmasına büyük önem verilen Avrupa'daki üniversite modellerinin farklı gelişim çizgilerini ve Türkiye'ye yansımalarını ortaya koymaktır. Bunun için gerekli literatür taraması yapılmış olup, belgeler toplanmış, ilgili araştırmalar elde edilmeye çalışılmış, çeşitli veri tabanlarında yayınlanan makaleler ve ana kaynaklar incelenmiş olup, ayrıca elektronik ortamda yer alan akademik metinlerden de yararlanılmıştır.

\section{Bulgular}

Gelişmiş veya gelişmekte olan ülkeler; ekonomik, sosyal ve kültürel gelişmişlik seviyesine katkıda bulunması için çeşitli yükseköğretim kurumları açarak, 
buralardan niteliksel ve niceliksel yetkin kadrolar yetiştirerek, ülkelerinin bilimsel ve teknolojik alanlarda ileri seviyeye yükseltmeye çalışarak kendi toplumlarının hizmetine sunarlar. Illk çağlardan itibaren çeşitli toplumlarda devlete ve milletlerine hizmet etmesi amacıyla fikri ve ilmi araştırmaların merkezinde yer alan yükseköğretim kurumları açılmaya başlanmıştır. Yükseköğretim kurumları arasında en seçkin yere sahip olan üniversiteler Avrupa'da 12. Yüzyıldan itibaren kurulmaya başlanır. Illk nüve olarak adlandırabileceğimiz bu dönemde açılmaya başlayan üniversitelerin ortak özelliklerinden birisi de örgütlenme biçimleriydi. Seçkin hocaların bir araya gelmesi ve etrafında da öğrencilerin toplanmaya başlamasıyla kendi aralarında hiyerarşik bir düzen kurarak kendilerine çeşitli dereceler vererek ve seçtikleri temsilciler aracılığıyla hem grup içi etkileşimi sağlamak hem de eğitim öğretim faaliyetlerinde bir özerkliğe kavuşarak yerel yöneticilerden veya halktan gelebilecek baskılara karşı koyabilmek için örgütlenirlerdi. Bu ilk üniversiteler İslam dünyasındaki yükseköğretim kurumlarına benzer şekilde sadece en üst dini kurumlarının etkisi altında olmasıydı. Yerel yönetim veya kiliselerin etkisi altına girmemeleri için direkt krallık veya Papalık himayesi altında kurulan bu ilk üniversiteler, İslam dünyasındaki önde gelen medreselerin tüm Müslüman halka uyguladığı şekilde, Hristiyan dünyasının farklı etnik bölgelerinden de Hristiyan öğrenci kabul etmeleri sonucu uluslararası bir statü kazanmışlardı. Bu dönem içerisinde faaliyete başlayan üniversitelerin getirdiği en önemli artı değerlerin başında skolastik düşüncenin dışında bilimsel gelişim ve araştırmaya değer verilmesinin ilk somut adımlarının atılması ile beraber, tabiat ve fen bilimlerine yönelik araştırmaların hızı bir şekilde artması, bu alanlara yönelik disiplinlerin çoğalması ve beraberinde akademik uzmanlaşmanın başlamasıdır. Bu dönemlerde İslam dünyası içerisinde yer alıp, fen ve tabiat ilimlerinde önde gelen yükseköğretim kurumları arasında olan bazı önemli medreselerde ise zaman içerisinde tersine bir süreç başlamış, bilimsel ve akademik araştırmalar gittikçe azalmıştır.

\section{Sonuç ve Tartışma}

Cumhuriyet Dönemi Türk Yükseköğretim sisteminin merkezinde yer alan üniversite kurumunun model alındığı Avrupa'daki üniversiteler bölgesel, yönetimsel ve kültürel bazı farklılıklar göstermekle beraber 19. Yüzyılda günümüzdeki modern hallerine kavuşmaya başlamışlardır. Bu dönemde dini otoritelerin gözetimi ve baskısı altından kurtulan üniversiteler önceleri zengin veya soylu ailelerin çocuklarının yararlandığı üst düzey eğitim merkezleri iken zamanla günümüzde toplumun tüm kesimlerinin katılabildiği kurumlara dönüştü. Türkiye'de de Osmanlı Devleti döneminde ilk kuruldukları anda toplumun sadece az bir kesiminin kayıt yaptırabildiği üniversiteler, cumhuriyet döneminde yapılan reformlar sayesinde halk tabanına yayılması sağlandı. Avrupa'daki üniversitenin 
gelişim modeline benzer şekilde hem Osmanlı Devleti hem de Türkiye Cumhuriyeti dönemlerinde hayata geçirilmeye çalışılan üniversite modeli geleneksel mirastan kopuş gayretini ifade eder. Avrupa'da kilise baskısından uzaklaştıkça bilimsel faaliyetleri artan, bu sayede de ülkelerinin teknolojik ve ekonomik kalkınmalarına büyük oranda destek veren üniversite modelini gören, önce ülkeyi işgalden kurtaran ve sonra da Türkiye Cumhuriyeti'nin kurulmasına ön ayak olan kurucu kadro, aynı şekilde üniversite kurumunun dini otoriteden uzak akademik ve bilimsel araştırmaların lokomotifi olacak bir kurum modeli olarak ülkemizde de yaygınlaşmasını öngörmüşlerdir. Bu sayede geleceğin yeni devlet kadrolarının oluşumunda önemli bir rol oynaması, ülkenin sosyal kültürel ve hatta siyasal alanlarındaki batıcı düşüncelerin gelişiminde merkez üs olması planlanmıştır. Farklı ülkelerde farklı şekilde uygulanmakta olan üniversite modelleri arasında ilk tercih edilen ise Fransız kurumlarıdır. Osmanlı Devleti'nin son dönemlerinde ve Cumhuriyetin ilk yıllarında kurulmaya başlanan fakülte ve üniversite örgütlenme şekli ile ders müfredatlarında Fransız modeli örnek alınır. İkinci Dünya Savaşı öncesi Türkiye'ye kaçarak gelen birçok Alman bilim adamlarının üniversitelerde istihdam edilmeleri ve onlarında katkıları ile hızlı bir şekilde bilimsel faaliyetler artmaya başlar. İkinci Dünya Savaşı sonrası dünya ile paralel bir şekilde Türkiye'de de Anglosakson etkisi ağır basmaya başlar. Bu dönemden sonra üniversiteler daha çok devletler ve piyasa ekonomisine hizmet etmeye başlar. Ulus devlete hizmet etme gayreti, üniversite kurumunun asli görevi olarak ortaya çıkar.

Adıyaman Üniversitesi Sosyal Bilimler Enstitüsü Dergisi, Yıl: 14, Sayı:38, Ağustos 2021 